\title{
The Draft Basic Law of the Hong Kong Special Administrative Region of the People's Republic of China for Solicitation of Opinions
}

Hong Kong SAR

Follow this and additional works at: https://scholarlycommons.law.case.edu/jil

Part of the International Law Commons

\section{Recommended Citation}

Hong Kong SAR, The Draft Basic Law of the Hong Kong Special Administrative Region of the People's Republic of China for Solicitation of Opinions, 20 Case W. Res. J. Int'l L. 301 (1988)

Available at: https://scholarlycommons.law.case.edu/jil/vol20/iss1/14 


\section{APPENDIX}

\section{The Draft Basic Law of the Hong Kong Special Administrative Region of the People's Republic of China for Solicitation of Opinions*}

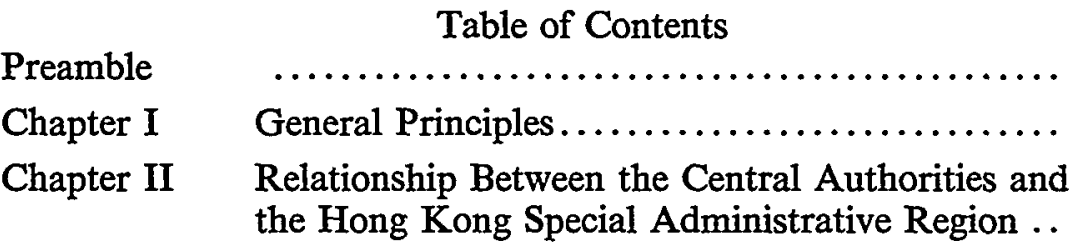
302

Chapter III Fundamental Rights and Duties of the Residents 303 Chapter IV Political Structure

Section 2

The Executive Authorities

Section 3

The Legislature

Section 4

Judicial Organs

Section 5

District Organizations .

Section 6

Chapter V

Public Servants

Economy ...

Section 1

Section 2

Public Finance and Taxation

Section 3

Section 4

Section 5

Section 6

Section 7

Money and Finance

External Trade and Economic Relations ........ 327

Industry, Commerce, and Other Trades...... 328

Land Leases ......................... 328

Shipping $\ldots \ldots \ldots \ldots \ldots \ldots \ldots \ldots \ldots \ldots \ldots, \quad 329$

Civil Aviation....................... 330

Chapter VI Education, Science, Culture, Sports, Religion, Labour, and Social Services.

* Issued by the Drafting Committee for the Basic Law of the Hong Kong Special Administrative Region of the People's Republic of China, April 1988. The introduction and summary compiled by the Secretariat of the Consultative Committee for the Basic Law have been omitted. The text was provided by the Hong Kong Economic Affairs Office, New York, New York. 
Chapter VII External Affairs ....................... 335

Chapter VIII The Regional Flag and Regional Emblem ...... 337

Chapter IX Interpretation and Amendment of the Basic Law 338

Chapter X Supplementary Provisions ................ 339

Annex I Methods for Selecting the Chief Executive of the Hong Kong Special Administrative Region ......

Annex II Method for Constituting the Legislative Council of the Hong Kong Special Administrative Region

Annex III Method for the Formation of the First

Government and the First Legislative Council of

the Hong Kong Special Administrative Region ..

A Collection of Opinions and Suggestions of Some Members in Regard to the Articles Drafted by Their Respective Special Subject Subgroups ................................

\section{Preamble}

Hong Kong has been part of China's territory since ancient times, but it was occupied by Britain after the Opium War in 1840 . On 19 December 1984, the Chinese and British governments signed the Joint Declaration on the Question of Hong Kong, affirming that the Government of the People's Republic of China will resume the exercise of sovereignty over Hong Kong on 1 July 1997, thus fulfilling the long-cherished common aspiration of the entire Chinese people for the recovery of Hong Kong.

In order to uphold national unity and territorial integrity and to maintain Hong Kong's prosperity and stability, and taking account of the history of Hong Kong and its realities, the People's Republic of China has decided that upon China's resumption of the exercise of sovereignty over Hong Kong, a Hong Kong Special Administrative Region will be established in accordance with the provisions of Article 31 of the Constitution of the People's Republic of China and that under the principle of "one country, two systems", socialist system and policies will not be practised in Hong Kong. The basic policies of the People's Republic of China regarding Hong Kong have been elaborated by our government in the Sino-British Joint Declaration.

In accordance with the Constitution of the People's Republic of China, the National People's Congress hereby enacts the Basic Law of the Hong Kong Special Administrative Region of the People's Republic of China, prescribing the systems to be practised in the Hong Kong Special Administrative Region, in order to ensure the implementation of the basic policies of the People's Republic of China regarding Hong Kong. 


\section{Chapter I: General Principles}

\section{Article 1}

The Hong Kong Special Administrative Region is an inalienable part of the People's Republic of China.

\section{Article 2}

The National People's Congress authorizes the Hong Kong Special Administrative Region to exercise a high degree of autonomy in accordance with the provisions of this Law and to enjoy executive, legislative and independent judicial power, including that of final adjudication.

\section{Article 3}

The executive authorities and legislature of the Hong Kong Special Administrative Region shall be composed of permanent residents of Hong Kong in accordance with the relevant provisions of this Law.

\section{Article 4}

Socialist system and policies shall not be practised in the Hong Kong Special Administrative Region and the existing capitalist system and way of life shall not be changed for 50 years.

\section{Article 5}

The Hong Kong Special Administrative Region safeguards the rights and freedoms of the residents and other persons in the Region in accordance with law.

\section{Article 6}

Rights of property ownership, including those relating to acquisition, use, disposal, inheritance and compensation for lawful take over [sic] shall be protected by law. The compensation for lawful takeover shall be corresponding to the real value of the property concerned, freely convertible and paid without undue delay.

\section{Article 7}

The land and natural resources within the Hong Kong Special Administrative Region are the state property of the People's Republic of China. The government of the Hong Kong Special Administrative Region shall be responsible for their management, use and development and for their lease or grant to individuals or legal persons for use or development. The revenue derived shall be entirely at the disposal of the government of the Hong Kong Special Administrative Region. 


\section{Article 8}

The laws previously in force in Hong Kong, that is, the common law, rules of equity, ordinances, subordinate legislation and customary law shall be maintained, except for those that contravene this Law or have been amended by the legislature of the Hong Kong Special Administrative Region.

\section{Article 9}

In addition to the Chinese language, the English language may also be used by the executive authorities, legislature and judicial organs of the Hong Kong Special Administrative Region.

\section{Article 10}

In accordance with Article 31 of the Constitution of the People's Republic of China, the policies and systems practised in the Hong Kong Special Administrative Region, including the social and economic systems, the system for safeguarding the fundamental rights and freedoms of its residents and the executive, legislative and judicial systems, shall be based on the provisions in this Law.

No law enacted by the legislature of the Hong Kong Special Administrative Region shall contravene this Law.

\section{Chapter II: Relationship Between the Central Authorities and the Hong Kong Special Administrative Region}

\section{Article 11}

The Hong Kong Special Administrative Region is a local administrative region of the People's Republic of China, enjoying a high degree of autonomy, and comes directly under the Central People's Government.

\section{Article 12}

The Central People's Government is responsible for the foreign affairs relating to the Hong Kong Special Administrative Region.

The Central People's Government authorizes the Hong Kong Special Administrative Region to deal with relevant external affairs on its own in accordance with this Law.

The Ministry of Foreign Affairs of the People's Republic of China will establish an office in Hong Kong to deal with foreign affairs. 


\section{Article 13}

The Central People's Government is responsible for the defence of the Hong Kong Special Administrative Region.

Military forces sent by the Central People's Government to be stationed in the Hong Kong Special Administrative Region for defence shall not interfere in the local affairs of the Region. The government of the Hong Kong Special Administrative Region may, in times of need, request the Central People's Government for assistance from the garrison in the maintenance of public order and disaster relief.

Apart from abiding by nation-wide laws, members of the garrison shall also abide by the laws of the Hong Kong Special Administrative Region.

All expenses for the garrison shall be borne by the Central People's Government.

\section{Article 14}

The Central People's Government appoints the Chief Executive and principal executive officials of the Hong Kong Special Administrative Region in accordance with the provisions of Chapter IV of this Law.

\section{Article 15}

The Hong Kong Special Administrative Region is vested with executive power. In accordance with the relevant provisions of this Law it shall, on its own, manage public finance, monetary matters, economy, industry and commerce, trade, taxation, postal service, civil aviation, maritime matters, traffic and transport, fishery, agriculture, personnel adminstration [sic], civil affairs, labour, education, medical and health services, social welfare, culture and recreation, municipal facilities, urban planning, housing, real estate, public order, entry and exit controls, meteorology, communications, science and technology, sports and other administrative affairs.

\section{Article 16}

The Hong Kong Special Administrative Region is vested with legislative power.

Laws enacted by the legislature of the Hong Kong Special Administrative Region shall be reported to the Standing Committee of the National People's Congress for the record. The reporting for record shall not affect the entry into force of such laws.

If the Standing Committee of the National People's Congress, after consulting its Committee for the Basic Law of the Hong Kong Special Administrative Region, considers that any law of the Region is not in 
conformity with this Law or legal procedures, it may return the law in question for reconsideration or revoke it, but it shall not amend it. Any law returned for reconsideration or revoked by the Standing Committee of the National People's Congress shall immediately cease to have force. This cessation shall not have retroactive effect.

\section{Article 17}

The Laws of the Hong Kong Special Administrative Region shall be this Law, the laws previously in force in Hong Kong as stipulated in Article 8 of this Law, and the laws enacted by the legislature of the Hong Kong Special Administrative Region.

Laws enacted by the National People's Congress or its Standing Committee will not be applied in the Hong Kong Special Administrative Region except for those stipulated in Paragraph 3 of this Article.

Laws, enacted by the National People's Congress or its Standing Committee, which relate to defence and foreign affairs as well as other laws which give expression to national unity and territorial integrity and which, in accordance with the provisions of this Law, are outside the limits of the high degree of autonomy of the Hong Kong Special Administrative Region shall be applied locally by the government of the Hong Kong Special Administrative Region by way of promulgation or legislation on the directives of the State Council, whenever there is the need to apply any of such laws in the Region.

Except in cases of emergency, the State Council shall consult the Committee for the Basic Law of the Hong Kong Special Administrative Region and the government of the Hong Kong Special Administrative Region before issuing the above-mentioned directives.

If the government of the Hong Kong [Special] Administrative Region fails to act in compliance with the directives given by the State Council, the State Council may decree the application of the above-mentioned law in the Hong Kong Special Administrative Region.

\section{Article 18}

The Hong Kong Special Administrative Region is vested with independent judicial power, including that of final adjudication.

Courts of the Hong Kong [Special] Administrative Region shall have jurisdiction over all cases in the Region, except that the restrictions of their jurisdiction imposed by Hong Kong's previous legal system shall be maintained.

Courts of the Hong Kong Special Administrative Region shall have no jurisdiction over cases relating to defence and foreign affairs, which are the responsibility of the Central People's Government, and cases relating to the executive acts of the Central People's Government. Courts 
of the Hong Kong Special Administrative Region shall seek the advice of the Chief Executive whenever questions concerning defence, foreign affairs or the executive acts of the Central People's Government arise in any legal proceeding. A statement issued by the Chief Executive regarding such questions shall be binding on the courts.

Before issuing such a statement, the Chief Executive shall obtain a certificate from the Standing Committee of the National People's Congress or the State Council.

\section{Article 19}

The Hong Kong Special Administrative Region may enjoy other powers granted to it by the National People's Congress, the Standing Committee of the National People's Congress or the State Council.

\section{Article 20}

Residents of the Hong Kong Special Administrative Region who are Chinese nationals are entitled to participate in state affairs as prescribed by law.

In accordance with the assigned number of seats and the election procedures specified by the Standing Committee of the National People's Congress, the Chinese nationals among the Hong Kong residents shall locally elect deputies of the Hong Kong Special Administrative Region to the National People's Congress to participate in the work of the highest organ of state power.

\section{Article 21}

Departments under the Central People's Government as well as provinces, autonomous regions and municipalities directly under the Central Government shall not interfere in the affairs which the Hong Kong Special Administrative Region administers on its own in accordance with this Law.

If departments under the Central Government, provinces, autonomous regions and municipalities directly under the Central Government need to set up offices in the Hong Kong Special Administrative Region, they must have the consent of the government thereof and the approval of the Central People's Government.

All offices set up in Hong Kong by the departments under the Central Government, or by provinces, autonomous regions and municipalities directly under the Central Government and personnel of these offices shall abide by the laws of the Hong Kong Special Administrative Region.

People from other parts of China must apply for approval for entry into the Hong Kong Special Administrative Region. 
The Hong Kong Special Administrative Region may establish an office in Beijing.

\section{Article 22}

The Hong Kong Special Administrative Region shall prohibit by law any act designed to undermine national unity or subvert the Central People's Government.

\section{CHAPTER III: FUNDAMENTAL RightS AND DUTIES OF THE RESIDENTS}

\section{Article 23}

Residents of the Hong Kong Special Administrative Region, or Hong Kong residents for short, include permanent residents and nonpermanent residents.

Permanent residents of the Hong Kong Special Administrative Region are:

(1) Chinese nationals born in Hong Kong before or after the establishment of the Hong Kong Special Administrative Region;

(2) Chinese nationals who have ordinarily resided in Hong Kong for a continuous period of no less than seven years before or after the establishment of the Hong Kong Special Administrative Region;

(3) Persons of Chinese nationality born outside Hong Kong of those residents listed in categories (1) and (2);

(4) Persons of non-Chinese nationality who have ordinarily resided in Hong Kong for a continuous period of no less than seven years and have taken Hong Kong as their place of permanent residence before or after the establishment of the Hong

- Kong Special Administrative Region;

(5) Persons under 21 years of age born in Hong Kong of residents listed in category (4) before or after the establishment of the Hong Kong Special Administrative Region; and

(6) Persons other than those residents listed in categories (1) to (5), who had the right of abode only in Hong Kong before the establishment of the Hong Kong Special Administrative Region.

The above-mentioned residents have the right of abode in the Hong Kong Special Administrative Region and are qualified to obtain, in accordance with its law, permanent identity cards which state their right of abode.

Non-permanent residents of the Hong Kong Special Administrative Region are persons who, in accordance with the laws of the Hong Kong Special Administrative Re- 
gion, are qualified to obtain Hong Kong identity cards but have no right of abode.

Article 24

All Hong Kong residents shall be equal before the law, regardless of their nationality, race, ethnic origin, language, sex, occupation, religious belief, political views, educational level and property status.

\section{Article 25}

Permanent residents of the Hong Kong Special Administrative Region who have reached the age of 21 shall have the right to vote and the right to stand for election as prescribed by law.

\section{Article 26}

Hong Kong residents shall have freedom of speech, of the press and of publication; freedom of association, to form and join trade unions, and to strike; and freedom of assembly and of demonstration.

\section{Article 27}

The freedom of the person of Hong Kong residents is inviolable.

Hong Kong residents shall not be unlawfully arrested, detained or imprisoned. Unlawful deprivation or restriction of the residents' freedom of the person by any means shall be prohibited. Unlawful search of the body of any resident shall be prohibited.

\section{Article 28}

The homes and other premises of Hong Kong residents shall not be violated. Unlawful search of, or intrusion into, a resident's home or other premises is prohibited.

\section{Article 29}

The freedom and privacy of communication of Hong Kong residents shall be protected by law. No department or individual may, on any ground, infringe upon the residents' freedom and privacy of communication except in cases where, to meet the needs of public security or of investigation into criminal offences, the relevant authorities may censor communication in accordance with legal procedures.

\section{Article 30}

Hong Kong residents shall have the freedom of movement within the Hong Kong Special Administrative Region and the freedom of emi- 
gration to other countries and regions. Hong Kong residents who hold valid travel documents shall have the freedom to travel and the freedom of entry and exit and, unless restrained by law, shall be free to leave the Hong Kong Special Administrative Region without special authorization.

Article 31

Hong Kong residents shall have the freedom of conscience.

Hong Kong residents shall have the freedom of religious belief and the freedom to preach and to carry out and participate in religious activities in public.

Article 32

Hong Kong residents shall have the freedom of choice of occupation.

Article 33

Hong Kong residents shall have the freedom of academic research, of literary and artistic creation, and of other cultural pursuits.

Article 34

Hong Kong residents shall have the right to confidential legal advice, access to the courts, and choice of lawyers for timely protection of their legitimate rights and interests, and for representation in the courts, and the right to judicial remedies.

Hong Kong residents shall have the right to challenge in the courts the actions of the executive organs or their personnel.

Article 35

Hong Kong residents shall have the right to social welfare; the welfare benefits of the working people shall be protected by law.

\section{Article 36}

The freedom of marriage of Hong Kong residents and their right to raise a family freely shall be protected by law.

Article 37

Hong Kong residents shall enjoy the other rights and freedoms safeguarded by the laws of the Hong Kong Special Administrative Region. 
Article 38

The provisions of the "International Covenant on Civil and Political Rights" and the "International Covenant on Economic, Social and Cultural Rights" as applied to Hong Kong shall be implemented through legislation by the Hong Kong Special Administrative Region.

\section{Article 39}

The rights and freedoms enjoyed by Hong Kong residents shall not be restricted unless prescribed by law. But such restrictions shall not go beyond the necessity for the maintenance of national security, public order, public safety, public health, public morals and for the safeguarding of the rights and freedoms of other persons.

\section{Article 40}

The legitimate traditional rights and interests of the indigenous inhabitants of "New Territories" shall be protected by the Hong Kong Special Administrative Region.

\section{Article 41}

Persons in the Hong Kong Special Administrative Region other than Hong Kong residents shall, in accordance with law, enjoy the rights and freedoms of Hong Kong residents prescribed in this Chapter.

\section{Article 42}

Hong Kong residents and other persons in Hong Kong shall have the obligation to abide by the laws of the Hong Kong Special Administrative Region.

\section{Chapter IV: Political Structure}

\section{Section 1: The Chief Executive}

Article 43

The Chief Executive of the Hong Kong Special Administrative Region is the head of the Hong Kong Special Administrative Region and represents the Region.

The Chief Executive of the Hong Kong Special Administrative Region shall be accountable to the Central People's Government and the Hong Kong Special Administrative Region in accordance with the provisions of this Law. 
Article 44

The Chief Executive of the Hong Kong Special Administrative Region shall be a Chinese national of no less than 40 years of age who is a permanent resident of the Region and has ordinarily resided in Hong Kong for a continuous period of 20 years.

\section{Article 45}

The Chief Executive of the Hong Kong Special Administrative Region shall be selected by election or through consultations held locally and be appointed by the Central People's Government.

The specific method for selecting the Chief Executive is prescribed in Annex I: "Method for Selecting the Chief Executive of the Hong Kong Special Administrative Region".

The method for selecting the Chief Executive as prescribed in Annex I may be modified in the light of actual situation in the Hong Kong Special Administrative Region and in accordance with the principle of gradual and orderly progress. Such modifications shall require the endorsement of a two-thirds majority of the members of the Legislative Council of the Hong Kong Special Administrative Region and the consent of the Chief Executive, and shall be submitted to the Standing Committee of the National People's Congress for approval.

\section{Article 46}

The term of office of the Chief Executive of the Hong Kong Special Administrative Region shall be five years. $\mathrm{He}$ /she may serve for no more than two terms.

\section{Article 47}

The Cheif [sic] Executive of the Hong Kong Special Administrative Region must be a person of integrity, dedicated to his/her duties.

The Chief Executive, on assuming office, shall declare his/her assets to the Chief Justice of the Court of Final Appeal of the Hong Kong Special Administrative Region. This declaration shall be put on record in strict confidence.

\section{Article 48}

The Chief Executive of the Hong Kong Special Administrative Region shall exercise the following powers and functions:

(1) To lead the government of the Region;

(2) To be responsible for the implementation of this Law and other laws which, in accordance with this Law, apply in the Hong Kong Special Administrative Region; 
(3) To sign bills passed by the Legislative Council and to promulgate laws;

To sign bills on budgets and final accounts passed by the Legislative Council and report them to the Central People's Government for the record;

(4) To decide on government policies and to issue executive orders;

(5) To nominate and to report to the Central People's Government for appointment the following principal officials: Secretaries and Deputy Secretaries of Departments, Directors of Bureaus, Commissioner Against Corruption, Director of Audit, Commissioner of Police and Commissioner of External Affairs *3; and to propose to the Central People's Government the removal of the above-mentioned officials;

To employ advisers at or above the director level as required and subject to the approval of the Central People's Government.

(6) To appoint or remove judges of the courts at various levels in accordance with legal procedures;

(7) To appoint or remove public servants in accordance with legal procedures;

(8) To implement the directives issued by the Central People's Government in respect of the relevant matters provided for in this Law;

(9) To deal with, on behalf of the government of the Hong Kong Special Administrative Region, external affairs and other affairs authorized by the Central Authorities;

(10) To approve the introduction of motions regarding revenues or expenditure to the Legislative Council;

(11) To decide, in the light of security and public interest, whether government officials or other personnel in charge of government affairs should testify or give evidence before the Legislative Council;

(12) To pardon persons convicted of criminal offences or commute their penalties; and

(13) To handle petitions and complaints.

Article 49

If the Chief Executive considers that a bill passed by the Legislative Council is not compatible with the overall interest of the Hong Kong Special Administrative Region, he/she may return it to the Legislative Council within three months for reconsideration. If the Legislative Council passes the original bill again by no less than a two-thirds major- 
ity, the Chief Executive must sign and promulgate it within one month, or act in accordance with the provisions of Article 50 of this Law.

Article 50

If the Chief Executive refuses to sign the bill passed by the Legislative Council for a second time, or the Legislative Council refuses to pass the budget or other important bills introduced by the government and if consensus still cannot be reached after consultations, the Chief Executive may dissolve the Legislative Council.

Before dissolving the Legislative Council the Chief Executive should ask for opinions from the Executive Council. A Chief Executive can dissolve the Legislative Council only once in each term of office.

\section{Article 51}

If the Legislative Council refuses to pass the budget bill presented by the government, or if appropriation of public funds cannot be approved because the Legislative Council is already dissolved, the Chief Executive may approve temporary short-term appropriations according to the level of the previous fiscal year's expenditure prior to the election of the new Legislative Council.

\section{Article 52}

The Chief Executive shall have to resign under any of the following circumstances:

(1) When he/she loses the ability to discharge the functions of his/her office due to serious illness or other reasons;

(2) When, after the Legislative Council is dissolved because he/she twice refuses to sign the bill it passes, the new Legislative Council has again passed the original bill in dispute with a twothirds majority; and

(3) When, after the Legislative Council is dissolved because it refuses to approve the budget or any other important bill, the new Legislative Council still refuses to pass the original bill in dispute.

\section{Article 53}

If the Chief Executive of the Hong Kong Special Administrative Region is not able to discharge his/her duties for a brief period, such duties shall temporarily be assumed by Administrative Secretary, Financial Secretary, Secretary of Justice in this order of precedence.

In the event that the office of Chief Executive becomes vacant, a new Chief Executive shall be selected within six months, and during the pe- 
riod of vacancy, his/her duties shall be assumed according to the provisions of the preceding Paragraph.

\section{Article 54}

The Executive Council of the Hong Kong Special Administrative Region is an organ for assisting the Chief Executive in policy-making.

\section{Article 55}

Members of the Executive Council of the Hong Kong Special Administrative Region shall be appointed by the Chief Executive from among the principal officials of the executive authorities, members of the Legislative Council and public figures. Their term of office and the termination of their appointment before their term expires shall be decided by the Chief Executive. The term of office of members shall not exceed that of the Chief Executive who appoints them.

Members of the Executive Council of the Hong Kong Special Administrative Region shall be Chinese nationals who are permanent residents of the Region.

The Chief Executive may invite other persons concerned to sit in at council meetings as he/she deems necessary.

\section{Article 56}

The Executive Council of the Hong Kong Special Administrative Region shall be presided over by the Chief Executive.

Except for the appointment, removal and disciplining of public officers and the adoption of measures in emergencies, the Chief Executive shall consult the Executive Council before making important decisions, introducing a bill to the Legislative Council, enacting subsidiary legislation, or dissolving the Legislative Council.

If the Chief Executive does not adopt a majority opinion of the Executive Council, he/she must put his/her specific reasons on record.

\section{Article 57}

A Commission Against Corruption shall be established in the Hong Kong Special Administrative Region. It shall function independently and be accountable to the Chief Executive.

\section{Article 58}

A Commission of Audit shall be established in the Hong Kong Special Administrative Region. It shall function independently and be accountable to the Chief Executive. 


\section{Section 2: The Executive Authorities}

Article 59

The government of the Hong Kong Special Administrative Region is the executive authorities of the Region.

\section{Article 60}

The Chief Executive of the Hong Kong Special Administrative Region is the head of the government of the Region.

Department of Administration, Department of Finance, Department of Justice, bureaus, divisions and commissions shall be established under the government of the Hong Kong Special Administrative Region.

The structure of the government of the Hong Kong Special Administrative Region shall be prescribed by law.

\section{Article 61}

The principal officials of the Hong Kong Special Administrative Region shall be Chinese nationals who are permanent residents and have ordinarily resided in Hong Kong for a continuous period of 15 years. *4

Article 62

The government of the Hong Kong Special Administrative Region shall exercise the following powers and functions:

(1) To formulate and implement policies;

(2) To manage the administrative affairs specified in Article 14 of this Law;

(3) To manage the external affairs authorized by the Central People's Government under this Law;

(4) To draw up and present budgets and final accounts; and

(5) To draft and introduce bills, motions and subsidiary legislation.

\section{Article 63}

The prosecuting authority of the Hong Kong Special Administrative Region shall institute criminal prosecutions independently, free from any interference.

\section{Article 64}

The executive authorities of the Hong Kong Special Administrative Region must abide by the law and shall be accountable to the Legislative Council of the Hong Kong Special Administrative Region in the following respects: They shall implement laws passed by the legislature and 
already in force; they shall present regular reports on their work to the Legislative Council; they shall answer questions raised by members of the Legislative Council; and they shall obtain approval from the Legislative Council for taxation and public expenditure.

Article 65

The establishment of advisory bodies under the executive authorities of the Hong Kong Special Administrative Region shall be maintained.

\section{SECTION 3: The Legislature}

Article 66

The Legislative Council of the Hong Kong Special Administrative Region *5 is the legislature of the Region.

Article 67

The Legislative Council of the Hong Kong Special Administrative Region shall be constituted by a combination of direct and indirect elections.

The specific methods for forming the Legislative Council are prescribed in Annex II: "Methods for Constituting the Legislative Council of the Hong Kong Special Administrative Region".

The methods for forming the Legislative Council provided in Annex II may be modified in the light of the actual situation in the Hong Kong Special Administrative Region and in accordance with the principle of gradual and orderly progress. Such modifications shall require the endorsement of a two-thirds majority of the members of the Legislative Council of the Region and the consent of the Chief Executive, and shall be submitted to the Standing Committee of the National People's Congress for approval.

Article 68

The term of office of members of the Legislative Council of the Hong Kong Special Administrative Region shall be four years.

Article 69

If the Legislative Council of the Hong Kong Special Administrative Region is dissolved by the Chief Executive in accordance with the provisions of this Law, it shall be reconstituted by election within three months as prescribed by Article 67 of this Law. 
Article 70

\section{Alternative 1:}

The president of the Legislative Council of the Hong Kong Special Administrative Region shall be elected from among the members of the Legislative Council.

The president of the Legislative Council of the Hong Kong Special Administrative Region shall be a Chinese national of no less than 40 years of age, who is a permanent resident of the Region and has ordinarily resided in Hong Kong for a continuous period of 20 years.

Alternative 2:

The Chief Executive shall concurrently be the president of the Legislative Council of the Hong Kong Special Administrative Region.

Article 71

The president of the Legislative Council of the Hong Kong Special Administrative Region shall exercise the following powers and functions:

(1) To preside over meetings;

(2) To decide on and control the agenda;

(3) To decide on the time and duration of meetings;

(4) To call special meetings during the recess; and

(5) Other powers and functions as prescribed in the rules of procedure of the Legislative Council.

Article 72

The Legislative Council of the Hong Kong Special Administrative Region shall exercise the following powers and functions:

(1) To enact, repeal or amend laws in accordance with the provisions of this Law and legal procedures;

(2) To examine and approve budgets and final accounts submitted by the executive authorities;

(3) To approve taxation and public expenditure;

(4) To hear and debate on the work reports of the Chief Executive;

(5) To raise questions on the work of the executive authorities;

(6) To hold debates on any issue concerning public interests;

(7) To endorse the appointment and removal of the judges of the Court of Final Appeal and the Chief Justice of the High Court;

(8) To receive and deal with complaints from Hong Kong inhabitants; and

(9) In the event of serious breach of law or dereliction of duty by the Chief Executive, an independent investigating committee, to be chaired by the Chief Justice of the Court of Final Appeal, on the motion initiated jointly by one-fourth of the members of the Legislative Council and passed by the council, may be es- 
tablished to carry out investigations and to report its findings to the council. If the committee considers the evidence sufficient, the council may pass a motion of impeachment with a two-thirds majority and report it to the Central People's Government for decision.

Article 73

Alternative 1:

Members of the Legislative Council of the Hong Kong Special Administrative Region may, in accordance with the provisions of this Law and legal procedures, individually or jointly introduce any bills. However written consent of the Chief Executive is required before the following three kinds of bills are introduced:

(1) Bills relating to revenue and expenditure;

(2) Bills relating to government policies; and

(3) Bills relating to the structure and operation of the government.

Alternative 2:

Members of the Legislative Council of the Hong Kong Special Administrative Region may, in accordance with the provisions of this Law and legal procedures, introduce bills. Bills which do not relate to public expenditure or public policies may be introduced individually or jointly by members of the council.

\section{Article 74}

The quorum for the meeting of the Legislative Council of the Hong Kong Special Administrative Region shall be no less than half of its members.

Unless otherwise provided for in this Law, the passage of any bill or motion in the Legislative Council of the Hong Kong Special Administrative Region requires the votes of more than half of its members present.

The rules of procedure of the Legislative Council shall be established by the council on its own, but they should not contravene this Law.

Article 75

A bill passed by the Legislative Council of the Hong Kong Special Administrative Region takes effect only after it is signed and promulgated by the Chief Executive.

Article 76

Members of the Legislative Council of the Hong Kong Special Ad- 
ministrative Region shall not be legally liable for speeches made at meetings of the council.

\section{Article 77}

Members of the Legislative Council of the Hong Kong Special Administrative Region shall not be subject to arrest when attending or on their way to a meeting of the Legislative Council.

\section{Article 78}

The president of the Legislative Council shall declare that a member of the council is no longer qualified to serve under any of the following circumstances $* 6$ :

(1) When he/she loses the ability to discharge the functions of his/her office due to serious illness or other reasons;

(2) When he/she is absent from meeting for three consecutive months without the consent of the president of the Legislative Council;

(3) When he/she loses or renounces his/her status as a permanent resident of the Hong Kong Special Administrative Region;

(4) When he/she is bankrupt or fails to pay debts in defiance of a court ruling;

(5) When he/she is convicted and sentenced to imprisonment for one month or more for a criminal offence committed within or outside the Hong Kong Special Administrative Region and is relieved of his/her duties by a motion passed by two-thirds of the members of the Legislative Council present; and

(6) When he/she is censored for misbehavior or breach of oath by a vote of two-thirds of the members of the Legislative Council present.

\section{SECtion 4: Judicial ORgans}

Article 79

The courts of the Hong Kong Special Administrative Region at various levels are the judicial organs of the Region, exercising the judicial power of the Region.

Article 80

The Court of Final Appeal, the High Court, district courts, magistrates' courts and other special courts are established in the Hong Kong Special Administrative Region. The High Court comprises the Court of Appeal and the Court of the First Instance.

The judicial system previously in practice in Hong Kong shall be 
maintained except for those changes consequent upon the establishment of the Court of Final Appeal in the Hong Kong Special Administrative Region.

\section{Article 81}

The Power of final adjudication of the Hong Kong Special Administrative Region is vested in the Court of Final Appeal in the Region, which may as required invite judges from other common law jurisdictions to sit on the Court of Final Appeal.

Article 82

The structure, powers and functions of the courts of the Hong Kong Special Administrative Region at various levels shall be prescribed by law.

Article 83

The courts of the Hong Kong Special Administrative Region decide cases in accordance with the laws applicable in the Region as prescribed in Article 17 of this Law and may refer to precedents in other common law jurisdictions.

\section{Article 84}

The courts of the Hong Kong Special Administrative Region exercise judicial power independently and free from any interference. Members of the judiciary are immune from legal action in respect of their judicial functions.

\section{Article 85}

The principle of trial by jury previously practised in Hong Kong shall be maintained.

\section{Article 86}

In criminal or civil proceedings in the Hong Kong Special Administrative Region, the principles previously applied in Hong Kong and the rights previously enjoyed by the parties to the proceedings shall be maintained.

\section{Article 87}

Judges of the courts of the Hong Kong Special Administrative Region *7 shall be appointed by the Chief Executive acting in accordance with the recommendation of an independent commission composed of 
local judges, persons from the legal profession and other eminent persons.

\section{Article 88}

A judge of a court of the Hong Kong Special Administrative Region may be removed for inability to discharge the functions of his/her office, or for misbehaviour, by the Chief Executive acting in accordance with the recommendation of a tribunal appointed by the Chief Justice of the Court of Final Appeal and consisting of no fewer than three local judges.

The Chief Justice of the Court of Final Appeal in the Hong Kong Special Administrative Region may be investigated for inability to discharge the functions of his/her office, or for misbehaviour, by a tribunal appointed by the Chief Executive and consisting of no fewer than five local judges and may be removed by the Chief Executive on the recommendation of the tribunal and in accordance with the procedures provided for in this Law.

\section{Article 89}

In addition to the procedures prescribed in Articles 87 and 88 of this Law, the appointment and removal of judges of the Court of Final Appeal and the Chief Justice of the High Court in the Hong Kong Special Administrative Region shall be made by the Chief Executive with the endorsement of the Legislative Council of the Region and reported to the Standing Committee of the National People's Congress for the record.

\section{Article 90}

The previous system of appointment and removal of members of the judiciary other than judges of the Hong Kong Special Administrative Region shall be maintained.

\section{Article 91}

Judges and other members of the judiciary of the Hong Kong Special Administrative Region shall be chosen by reference to their judicial and professional qualities and may be recruited from other common law jurisdictions.

\section{Article 92}

Judges and other members of the judiciary serving in Hong Kong before the establishment of the Hong Kong Special Administrative Region may all remain in employment and retain their seniority with pay, allowances, benefits and conditions of service no less favourable than before. 
Article 93

The Hong Kong Special Administrative Region shall pay to judges and other members of the judiciary who retire or leave the service in compliance with regulations as well as to those who have retired or left the service before the establishment of the Hong Kong Special Administrative Region, or to their dependents, all pensions, gratuities, allowances and benefits due to them on terms no less favourable than before, and irrespective of their nationality or place of residence.

Article 94

The judicial organs of the Hong Kong Special Administrative Region may, through consultation and in accordance with law, maintain judicial relations with those of other parts of the country, and they may render assistance to each other.

\section{Article 95}

With the assistance or authorization of the Central People's Government, the government of the Hong Kong Special Administrative Region may make appropriate arrangements with foreign states for reciprocal judicial assistance.

\section{SEction 5: District ORganizations}

\section{Article 96}

District organizations which are not local organs of political power may be established in the Hong Kong Special Administrative Region, to be consulted by the government of the Region on district administration and other affairs, or to be responsible for providing services in such fields as culture, recreation and environmental sanitation. *8

\section{Article 97}

The powers and functions of the district organizations and their composition shall be prescribed by law.

\section{Section 6: Public Servants}

\section{Article 98}

Public servants serving in all government departments of the Hong Kong Special Administrative Region must be permanent residents of the Region, except where otherwise provided for in Article 100 of this Law and except for those below a certain salary point as prescribed by law.

Public servants must be dedicated to their duties and be responsible to the government of the Hong Kong Special Administrative Region. 


\section{Article 99}

Public servants serving in all Hong Kong government departments, including the police department, before the establishment of the Hong Kong Special Administrative Region, may all remain in employment and retain their seniority with pay, allowances, benefits and conditions of service no less favourable than before.

\section{Article 100}

The government of the Hong Kong Special Administrative Region may employ British and other foreign nationals previously serving in the public service in Hong Kong, or those holding permanent identity cards of the Region to serve as public servants at various levels, but only Chinese nationals among permanent residents of the Region can fill the following posts: the Secretary and Deputy Secretaries of Departments, Directors of Bureaus, Commissioner Against Corruption, Director of Audit, Deputy Directors for Security and for Civil Service, Commissioner and Deputy Commissioners of Police, Commissioner and Deputy Commissioners of External Affairs, Commissioner of Immigration and Inspector General of Customs and Excise.

The government of the Hong Kong Special Administrative Region may also employ British and other foreign nationals as advisers to government departments and, when there is need, may recruit qualified candidates from outside the Region to professional and technical posts in government departments. These foreign nationals shall be employed only in their individual capacities and shall be responsible to the government of the Region.

\section{Article 101}

The government of the Hong Kong Special Administrative Region shall pay to public servants who retire or leave the service in compliance with regulations as well as to those who have retired or left the service in compliance with regulations before the establishment of the Hong Kong Special Administrative Region, or to their dependents, all pensions, gratuities, allowances and benefits due to them on terms no less favourable than before, and irrespective of their nationality or place of residence.

\section{Article 102}

The appointment and promotion of public servants shall be on the basis of their qualifications, experience and ability. Hong Kong's previous system of recruitment, employment, assessment, discipline, training and management for the public service, including special bodies for their 
appointment, pay and conditions of service, shall be maintained, except for any provisions for privileged treatment of foreign nationals.

Article 103

The Chief Executive, principal officials, members of the Executive Council and of the Legislative Council, judges of courts at all levels and other members of the judiciary in the Hong Kong Special Administrative Region must be sworn in according to law when assuming office.

\section{CHAPTER V: ECONOMY}

\section{Section 1: Public Finance and Taxation}

Article 104

The Hong Kong Special Administrative Region shall have independent finances.

The Hong Kong Special Administrative Region shall use its financial revenues exclusively for its own purposes, and they shall not be handed over to the Central People's Government.

Article 105

The government of the Hong Kong Special Administrative Region shall follow the principle of measuring expenditure by revenues in drawing up its budget.

The government of the Hong Kong Special Administrative Region shall, over a number of fiscal years taken as a whole, maintain a basic balance between total budgetary revenues and expenditure.

In principle, the rate of increase of the budgetary revenues and the expenditure of the Hong Kong Special Administrative Region shall not exceed that of the gross domestic product over a number of fiscal years taken as a whole.

Article 106

The Hong Kong Special Administrative Region shall practise an independent taxation system.

The Central People's Government shall not levy taxes in the Hong Kong Special Administrative Region.

\section{Article 107}

The Hong Kong Special Administrative Region shall continue to practise a low tax policy. 
Article 108

The types of taxes, the tax rates and tax exemptions in the Hong Kong Special Administrative Region shall be prescribed by law.

\section{SECTION 2: MONEY AND FINANCE}

Article 109

The government of the Hong Kong Special Administrative Region shall create conditions and take measures for the maintenance of the status of the Hong Kong Special Administrative Region as an international financial centre.

Article 110

The Hong Kong Special Administrative Region shall continue to practise free and open monetary and financial policies. Its monetary and financial systems shall be governed by law.

\section{Article 111}

No exchange control policies shall be applied in the Hong Kong Special Administrative Region. Markets for foreign exchange, gold, securities and futures shall continue.

Article 112

The government of the Hong Kong Special Administrative Region shall safeguard the free flow of all capital within, into and out of the Region.

\section{Article 113}

The government of the Hong Kong Special Administrative Region shall safeguard the free operation of financial business and financial markets and shall regulate and supervise them in accordance with law.

Article 114

The Hong Kong dollar, as the legal tender in the Hong Kong Special Administrative Region, shall continue to circulate and remain freely convertible.

Article 115

The authority to issue Hong Kong currency shall be vested in the government of the Hong Kong Special Administrative Region. The system regarding the issue of Hong Kong currency shall be prescribed by law. 
The issue of Hong Kong currency shall be backed up by a reserve fund of no less than 100 per cent freely convertible foreign currency.

The government of the Hong Kong Special Administrative Region may authorize designated banks to issue or continue to issue Hong Kong currency under statutory authority, after satisfying itself that any issue of currency will be soundly based and that the arrangements for such issue are consistent with the object of maintaining the stability of the currency.

Article 116

The Exchange Fund of the Hong Kong Special Administrative Region shall be managed and controlled by the government of the Region, primarily for regulating the exchange value of the Hong Kong dollar.

\section{Section 3: External Trade and Economic Relations} Article 117

The Hong Kong Special Administrative Region shall continue the policy of free external trade and free external economic relations.

The government of the Hong Kong Special Administrative Region shall safeguard the free movement of goods, intangible assets and capital.

Investments from outside the Region shall be protected by law.

\section{Article 118}

The Hong Kong Special Administrative Region shall remain a free port.

The Hong Kong Special Administrative Region shall not impose any tariff unless otherwise stipulated by law.

\section{Article 119}

The Hong Kong Special Administrative Region shall be a separate customs territory.

The Hong Kong Special Administrative Region may, using the name "Hong Kong, China", participate in relevant international organizations and international trade agreements, including preferential trade arrangements, such as the General Agreement on Tariffs and Trade and arrangements regarding international trade in textiles.

\section{Article 120}

Export quotas, tariff preferences and other similar arrangements, which are obtained by the Hong Kong Special Administrative Region or which were obtained and remain valid, shall be enjoyed exclusively by the Region. 


\section{Article 121}

The Hong Kong Special Administrative Region may issue its own certificates of origin for products manufactured locally in accordance with prevailing rules of origin.

\section{SECTION 4: INDUSTRY, COMMERCE AND OTHER TRADES} Article 122

The Hong Kong Special Administrative Region shall practise free and open policies regarding industry, commerce and other trades.

\section{Article 123}

The government of the Hong Kong Special Administrative Region shall create the necessary environment and conditions for encouraging industrial investment, technological progress and the development of new industries.

\section{Article 124}

The government of the Hong Kong Special Administrative Region shall formulate appropriate policies to promote and co-ordinate the development of various trades such as commerce, tourism, real estate, transport, public utilities, services, agriculture and fishery.

\section{SECTION 5: LAND LEASES}

\section{Article 125}

The government of the Hong Kong Special Administrative Region may, on its own, formulate policies regarding the development, management and use of land.

\section{Article 126}

All leases of land granted, decided upon or renewed before the establishment of the Hong Kong Special Administrative Region which extend beyond 30 June 1997, and all rights in relation to such leases, shall continue to be recognized and protected under the law of the Region.

Article 127

As regards leases of land granted or renewed where the original leases contain no right of renewal, during the period from 27 May 1985 to 30 June 1997, which extend beyond 30 June 1997 and expire not later than 30 June 2047, the lessee is not required to pay an additional premium as from 1 July 1997, but an annual rent equivalent to 3 per cent of 
the rateable value of the property at that date, adjusted in step with any changes in the rateable value thereafter shall be charged.

\section{Article 128}

In the case of old schedule lots, village lots, small houses and similar rural holdings, where the property was on 30 June 1984 held by, or, in the case of small houses granted after that date, where property is granted to, a person descended through the male line from a person who was in 1898 a resident of an established village in Hong Kong, the previous rent shall remain unchanged so long as the property is held by that person or by one of his lawful successors in the male line.

\section{Article 129}

Where leases of land without a right of renewal expire after the establishment of the Hong Kong Special Administrative Region, they shall be dealt with in accordance with laws and policies formulated by the Region on its own.

\section{SECTION 6: SHIPPING}

\section{Article 130}

The Hong Kong Special Administrative Region shall maintain Hong Kong's previous systems of shipping management and shipping regulation.

The specific functions and responsibilities of the government of the Hong Kong Special Administrative Region in respect of shipping shall be defined by it on its own.

\section{Article 131}

The Hong Kong Special Administrative Region shall be authorized by the Central People's Government to continue to maintain a shipping register and issue related certificates under its own legislation using the name "Hong Kong, China".

\section{Article 132}

With the exception of foreign warships, access for which requires the special permission of the Central People's Government, ships shall enjoy access to the ports of the Hong Kong Special Administrative Region in accordance with the laws of the Region.

\section{Article 133}

Private shipping businesses and shipping-related businesses and pri- 
vate container terminals in the Hong Kong Special Administrative Region may continue to operate freely.

\section{Section 7: Civil Aviation}

\section{Article 134}

The government of the Hong Kong Special Administrative Region shall create conditions and take measures for the maintenance of the status of the Region as a centre of international and regional aviation.

\section{Article 135}

The Hong Kong Special Administrative Region shall continue the previous system of civil aviation management in Hong Kong and keep its own aircraft register in accordance with provisions laid down by the Central People's Government concerning nationality marks and registration marks of aircraft.

Access of foreign military aircraft to the Hong Kong Special Administrative Region requires the special permission of the Central People's Government.

\section{Article 136}

The Hong Kong Special Administrative Region shall be responsible on its own for matters of routine business and technical management of civil aviation, including the management of airports, the provision of air traffic services within the flight information region of the Hong Kong Special Administrative Region, and the discharge of other responsibilities allocated to it under the regional air navigation procedures of the International Civil Aviation Organization.

\section{Article 137}

The Central People's Government shall, in consultation with the government of the Hong Kong Special Administrative Region, make arrangements providing for air services between the Region and other parts of the People's Republic of China for airlines incorporated in the Hong Kong Special Administrative Region and having their principal place of business in Hong Kong and other airlines of the People's Republic of China.

\section{Article 138}

All air service agreements providing for air services between other parts of the People's Republic of China and other states and regions with stops at the Hong Kong Special Administrative Region and for air services between the Hong Kong Special Administrative Region and other 
states and regions with stops at other parts of the People's Republic of China shall be concluded by the Central People's Government.

In concluding the international air service agreements referred to in the first Paragraph of this Article, the Central People's Government shall take account of the special conditions and economic interests of the Hong Kong Special Administrative Region and consult the government of the Region.

Representatives of the government of the Hong Kong Special Administrative Region may participate, as members of the delegations of the Government of the People's Republic of China, in air service consultations with foreign governments concerning arrangements for such services referred to in the first Paragraph of this Article.

\section{Article 139}

Acting under specific authorizations from the Central People's Government, the government of the Hong Kong Special Administrative Region may:

(1) renew or amend air service agreements and arrangements previously in force;

(2) negotiate and conclude new air service agreements providing routes for airlines incorporated in the Hong Kong Special Administrative Region and having their principal place of business in Hong Kong and rights for over-flights and technical stops; and

(3) negotiate and conclude provisional arrangements where no air service agreement with a foreign state or with another region is in force.

All scheduled air services to, from or through Hong Kong, which do not operate to, from or through the mainland of China shall be regulated by the air service agreements or provisional arrangements referred to in this Article.

\section{Article 140}

The Central People's Government shall give the government of the Hong Kong Special Administrative Region the authority to:

(1) negotiate andi conclude with other authorities all arrangements concerning the implementation of the air service agreements and provisional arrangements referred to in Article 139 of this Law;

(2) issue licences to airlines incorporated in the Hong Kong Special Administrative Region and having their principal place of business in Hong Kong;

(3) designate such airlines under the air service agreements and 
provisional arrangements referred to in Article 139 of this Law; and

(4) issue permits to foreign airlines for services other than those to, from or through the mainland of China.

\section{Article 141}

Airlines incorporated and having their principal place of business in Hong Kong and civil aviation related businesses there before the establishment of the Hong Kong Special Administrative Region may continue to operate.

Chapter Vi: Education, Science, Culture, Sports, Religion, LABOUR AND SOCIAL SERVICES

Article 142

The Hong Kong Special Administrative Region shall maintain the educational system previously practised in Hong Kong.

\section{Article 143}

The Government of the Hong Kong Special Administrative Region shall, on its own, formulate policies on education, including policies regarding the educational system and its administration, the language of instruction, the allocation of funds, the examination system, the system of academic awards and the recognition of educational qualifications.

Community organizations and individuals may, in accordance with law, run educational undertakings of various kinds in the Hong Kong Special Administrative Region.

\section{Article 144}

Educational institutions of all kinds may retain their autonomy and enjoy academic freedom. They may continue to recruit staff and use teaching materials from outside the Hong Kong Special Administrative Region. Schools run by religious organizations may continue to provide religious education, including courses on religion.

Students shall enjoy freedom to choose between educational institutions and to pursue their education outside the Hong Kong Special Administrative Region.

\section{Article 145}

The government of the Hong Kong Special Administrative Region shall promote the development of medical and health services and the development of Western and Chinese traditional medicine, and en- 
courage community organizations and individuals to provide medical and health services of various kinds.

\section{Article 146}

The government of the Hong Kong Special Administrative Region shall, on its own, formulate policies on science and technology. The Hong Kong Special Administrative Region shall protect, by law, achievements in scientific and technological research, patents, discoveries and inventions.

The government of the Hong Kong Special Administrative Region shall, on its own, decide on the scientific and technological standards and specifications applicable in Hong Kong.

\section{Article 147}

The government of the Hong Kong Special Administrative Region shall, on its own, formulate policies on culture and protect the achievements and the legitimate rights and interests of authors in their literary and artistic pursuits.

\section{Article 148}

The government of the Hong Kong Special Administrative Region shall not interfere in the internal affairs of religious organizations and shall not restrict religious activities which do not contravene the laws of the Region.

Religious organizations shall, in accordance with law, enjoy the rights to acquire, use, dispose of and inherit property and the right to receive financial assistance. Their previous property rights and interests shall be maintained and protected.

Religious organizations may, according to their previous practice, continue to run seminaries and other schools, hospitals and welfare institutions and to provide other social services.

\section{Article 149}

Religious organizations and believers in the Hong Kong Special Administrative Region may maintain and develop their relations with religious organizations and believers elsewhere.

\section{Article 150}

The government of the Hong Kong Special Administrative Region shall, on its own, decide on the methods of assessing and accrediting qualifications for professional practice for the various professions. The 
methods of assessing and accrediting qualifications previously practised in Hong Kong may be maintained and perfected.

Persons with professional qualifications or qualifications for professional practice obtained prior to the establishment of the Hong Kong Special Administrative Region may retain their previous qualifications.

The Hong Kong Special Administrative Region shall maintain the professions and the professional organizations recognized prior to the establishment of the Region, and these organizations may, on their own, assess and accredit professional qualifications.

The government of the Hong Kong Special Administrative Region may, as required by developments in society and in consultation with the parties concerned, recognize new professions and professional organizations.

\section{Article 151}

The government of the Hong Kong Special Administrative Region shall, on its own, formulate policies on sports. Previous non-governmental sports organizations may continue to exist and develop in accordance with law.

\section{Article 152}

The Hong Kong Special Administrative Region shall maintain the policy previously practised in Hong Kong in respect of subventions for organizations in fields such as education, medicine, culture, arts, recreation, sports, social welfare and social work. Staff previously serving in subventioned organizations in Hong Kong may remain in their employment in accordance with the previous system.

\section{Article 153}

The government of the Hong Kong Special Administrative Region shall maintain the previous social welfare system and shall formulate, on its own, policies on the development and improvement of this system in the light of the economic conditions and social needs.

\section{Article 154}

Voluntary organizations providing social services in the Hong Kong Special Administrative Region may, on their own, decide their forms of service in accordance with law.

\section{Article 155}

The Hong Kong Special Administrative Region shall, on its own, formulate labour laws and policies in the light of economic development, 
social needs and the specific circumstances of labour-management consultations.

\section{Article 156}

The relationship between non-governmental organizations in fields such as education, science, technology, culture, sports, the professions and social welfare as well as religious organizations in the Hong Kong Special Administrative Region and their counterparts on the mainland shall be in conformity with the principles of non-subordination, non-interference and mutual respect.

\section{Article 157}

Organizations in fields such as education, science, technology, culture, sports, health, the professions, labour, social welfare and religion in the Hong Kong Special Administrative Region may maintain and develop relations with foreign countries and other regions and with relevant international organizations. They may, as required, use the name, "Hong Kong, China" in the relevant activities.

\section{ChAPTER VII: EXTERNAL AfFAIRS}

Article 158

Representatives of the government of the Hong Kong Special Administrative Region may participate, as members of delegations of the Government of the People's Republic of China, in negotiations at the diplomatic level directly affecting the Region conducted by the Central People's Government.

\section{Article 159}

The Hong Kong Special Administrative Region may, on its own, using the name "Hong Kong, China", maintain and develop relations and conclude and implement agreements with states, regions and relevant international organizations in the appropriate fields, including the economic, trade, financial and monetary, shipping, communications, tourism, cultural and sports fields.

\section{Article 160}

Representatives of the Hong Kong Special Administrative Region may participate, as members of delegations of the Government of the People's Republic of China, in international organizations or conferences in appropriate fields limited to states and affecting the Region, or may attend in such other capacity as may be permitted by the Central People's Government and the international organization or conference con- 
cerned, and may express their views, using the name "Hong Kong, China".

The Hong Kong Special Administrative Region may, using the name "Hong Kong, China", participate in international organizations and conferences not limited to states.

The Central People's Government shall take the necessary steps to ensure that the Hong Kong Special Administrative Region shall continue to retain its status in an appropriate capacity in those international organizations of which the People's Republic of China is a member and in which Hong Kong participates in one capacity or another.

The Central People's Government shall, where necessary, facilitate the continued participation of the Hong Kong Special Administrative Region in an appropriate capacity in those international organizations in which Hong Kong is a participant in one capacity or another, but of which the People's Republic of China is not a member.

\section{Article 161}

The application to the Hong Kong Special Administrative Region of international agreements to which the People's Republic of China is or becomes a party shall be decided by the Central People's Government, in accordance with the circumstances and needs of the Region, and after seeking the views of the government of the Region.

International agreements to which the People's Republic of China is not a party but which are implemented in Hong Kong may continue to be implemented in the Hong Kong Special Administrative Region. The Central People's Government shall, as necessary, authorize or assist the government of the Region to make appropriate arrangements for the application to the Region of other relevant international agreements.

\section{Article 162}

The Central People's Government shall authorize the government of the Hong Kong Special Administrative Region to issue, in accordance with law, passports of the Hong Kong Special Administrative Region of the People's Republic of China to all Chinese nationals who hold permanent identity cards of the Region, and travel documents of the Hong Kong Special Administrative Region of the People's Republic of China to all other persons lawfully residing in the Region. The above passports and documents shall be valid for all states and regions and shall record the holder's right to return to Hong Kong.

The government of the Hong Kong Special Administrative Region may apply immigration controls on entry into, stay in and departure from the Hong Kong Special Administrative Region by persons from foreign states and other regions. 
Article 163

The Central People's Government shall assist or authorize the government of the Hong Kong Special Administrative Region to conclude visa exemption agreements with states or regions.

Article 164

The Hong Kong Special Administrative Region may, as necessary, establish official or semi-official economic and trade missions in foreign countries and shall report the establishment of such missions to the Central People's Government for the record.

Article 165

The establishment of foreign consular and other official or semi-offcial missions in the Hong Kong Special Administrative Region requires the approval of the Central People's Government.

Consular and other official missions established in Hong Kong by states which have formal diplomatic relations with the People's Republic of China may be maintained.

According to the circumstances of each case, consular and other official missions established in Hong Kong by states which have no formal diplomatic relations with the People's Republic of China may either be permitted to remain or be changed to semi-official missions.

States not recognized by the People's Republic of China can only establish non-governmental institutions in Hong Kong.

Chapter VIII: The Regional Flag and Regional Emblem of the HoNg Kong SPecial Administrative Region

Article 166

Apart from displaying the national flag and national emblem, the Hong Kong Special Administrative Region may use a regional flag and regional emblem of its own (to be drafted).

Article 167

The regional flag of the Hong Kong Special Administrative Region (to be drafted).

Article 168

The regional emblem of the Hong Kong Special Administrative Region (to be drafted). 


\section{CHAPTER IX: INTERPRETATION AND AMENDMENT OF THE BASIC LAW}

Article 169

The power of interpretation of this Law is vested in the Standing Committee of the National People's Congress.

When the Standing Committee of the National People's Congress makes an interpretation of a provision of this Law, the courts of the Hong Kong Special Administrative Region, in applying that provision, shall follow the interpretation of the Standing Committee. However, judgments previously rendered shall not be affected.

The courts of the Hong Kong Special Administrative Region may interpret the provisions of this Law in adjudicating cases before them. If a case involves an interpretation of the provisions of this Law concerning defence, foreign affairs and other affairs whcih [sic] are the responsibility of the Central People's Government, the courts of the Region, before making their final judgment on the case, shall seek an interpretation of the relevant provisions from the Standing Committee of the National People's Congress.

The Standing Committee of the National People's Congress shall consult its Committee for the Basic Law of the Hong Kong Special Administrative Region before giving an interpretation of this Law.

\section{Article 170}

The power of amendment of this Law is vested in the National People's Congress.

The right to propose amendments to this Law rests with the Standing Committee of the National People's Congress, the State Council and the Hong Kong Special Administrative Region. Amendmentt [sic] proposals from the Hong Kong Special Administrative Region shall be submitted to the National People's Congress by the delegation of the Region to the National People's Congress after obtaining the consent of twothirds of the deputies of the Region to the National People's Congress, two-thirds of all the members of the legislature of the Region, and the Chief Executive of the Region.

Before a proposal for an amendment to this Law is put on the agenda of the National People's Congress, the Committee for the Basic Law of the Hong Kong Special Administrative Region shall first study it and submit its views.

No amendment to this Law shall contravene the established basic policies of the People's Republic of China regarding Hong Kong. 


\section{Chapter X: Supplementary Provisions}

Article 171

The first government and the first Legislative Council of the Hong Kong Special Administrative Region shall be established in accordance with the principles of national sovereignty and of smooth transition and in accordance with the stipulations of Annex III: "Method for the Formation of the First Government and the First Legislative Council of the Hong Kong Special Administrative Region".

\section{Article 172}

At the time of the establishment of the Hong Kong Special Administrative Region, the laws previously in force in Hong Kong shall be adopted as laws of the Region except for those which the Standing Committee of the National People's Congress declares to be in contravention of this Law. If any laws are later discovered to be in contravention of this Law, they can be annuled or revised according to the procedure as prescribed by this Law.

Documents, certificates, contracts, and rights and obligations valid under the laws previously in force in Hong Kong shall continue to be valid and be recognized and protected by the laws of the Hong Kong Special Administrative Region, provided that they do not contravene this Law. 


\section{Annex I Method for Selecting the Chief Executive of the Hong Kong Special Administrative Region}

\section{Alternative 1}

1. The Chief Executive of the Hong Kong Special Administrative Region shall be elected locally by a broadly representative electoral college.

2. The electoral college shall be composed of about 600 representatives from various walks of life in Hong Kong, including members of the legislature; representatives of district organizations; representatives of corporate bodies and non-corporate permanent organizations; and representatives of various functional constituencies (including industry, commerce, finance, professions, education, labour, religious communities, social services and the public servants).

3. Communities and organizations with seats in the electoral college may, according to their own rules, elect their representatives by a democratic procedure. Each elected representative must not concurrently represent several organizations and shall vote in an individual capacity. The electoral college will be dissolved after the election is completed.

4. The electoral college shall elect a nominating committee of 20 members from its own midst. The committee shall nominate three candidates for the office of the Chief Executive. Members of the nominating committee cannot run for the office of the Chief Executive, nor can they vote in the election of the Chief Executive.

5. The electoral college shall vote on the nominations by the nominating committee, and a candidate must win over half of the votes to be elected. If no one wins over half of the votes on the first ballot, a second ballot has to be taken on the two candidates with the highest number of votes. The Chief Executive elected by the electoral college shall be reported to the Central People's Government for appointment.

6. Detailed election rules shall be prescribed by the laws of the government of the Hong Kong Special Administrative Region.

Alternative 2

1. The Chief Executive of the Hong Kong Special Administrative Region shall be nominated by no less than one-tenth of the 
members of the legislature, and directly elected by a general election held throughout Hong Kong.

2. Each member of the legislature can nominate only one candidate for the Chief Executive.

3. The election for the Chief Executive must be genuine and held at regular intervals. The right to vote must be universal and equal. Election should be by secret ballot to ensure free expression of the will of the voters.

4. If the elected Chief Executive is a member of the legislature, the executive authorities, or the judicial organs, he/she must resign from his/her original post upon election.

5. Detailed rules for the election of the Chief Executive shall be prescribed by the laws of the Hong Kong Special Administrative Region.

\section{Alternative 3}

1. The Chief Executive shall be elected by a functional electoral college on a one-person-one-vote basis.

2. The functional electoral college shall have no more than 600 members and be composed of representatives elected from among the permanent residents of the Hong Kong Special Administrative Region, who belong to business, finance, professional, labour and other organizations which have an influence on the operation of the government and social services. The proportions of representation shall be as follows:

Business and financial organizations

Professional bodies

Labour organizations

Religious, social welfare and philanthropic institutions

Area committees and street vendors'

organizations

3. Any person with qualifications prescribed by Article 44 of this Law and nominated by no less than 50 permanent residents of Hong Kong can become a candidate for the Chief Executive of the Hong Kong Special Administrative Region.

4. Members of the electoral college shall not nominate or be nominated as candidates. Nominators shall not be members of the electoral college or be candidates. Candidates shall not be 
members of the electoral college or nominators of other candidates.

\section{Alternative 4}

1. The selection of the first Chief Executive is specified in other provisions. The second or third Chief Executives shall be selected by an advisory group through consultation.

The advisory group shall be composed of 50-100 advisers. Candidates for advisers shall be nominated by different circles in Hong Kong, selected by the Executive Council and then appointed by the Chief Executive after approval by the Central People's Government. (These are special political advisers, different from other professional advisers.)

Each advisory group must be formed six months before the term of office of the incumbent Chief Executive expires. But if the advisory group and the Central People's Government endorse him/her for another term, the next advisory group need not be formed.

2. Subsequent Chief Executives shall be elected by an electoral college.

The electoral college shail be composed of former members of the Legislative Council, former members of the Executive Council, former Chief Executives, and former principal officials appointed by the Central People's Government. The first electoral college cannot be formed with less than 250 members. The number may gradually increase in the successive electoral colleges, but shall not exceed 500 . Once that number is exceeded, members will have to resign in the order of their length in office. If their length in office is the same, the member elder in age shall resign first.

Three candidates for the office of the Chief Executive shall be nominated by the advisory group and, after the approval of the Central PEople's Government, the Chief Executive shall be voted on by the electoral college.

Alternative 5

1. The Chief Executives shall be elected by all the voters of Hong Kong on a one-person-one-vote basis. Three candidates shall be nominated, through onsultation [sic] or by ballot after consultation, by the "Nominating Committee for the Election of the Chief Executive of the Hong Kong Special Administrative Region".

2. The "Nominating Committee" shall be composed of permanent 
residents of Hong Kong who must be broadly representative, including deputies of the Hong Kong region to the National People's Congress, members of the National Committee of the Chinese People's Political Consultative Conference from the Hong Kong region, representatives from Hong Kong's legislature and from district organizations, and from other strata and sections of society in Hong Kong.

3. The proportions of representation of the "Nominating Committee" shall be as follows:

Representatives of business and financial circles $25 \%$

Representatives of professional bodies $25 \%$

Representatives of labour, grass-roots and religious organizations

$25 \%$

Members of the legislature

$12 \%$

Members of district organizations

Deputies to the National People's Congress and members of the National Committee of the Chinese People's Political Consultative Conference

4. The "Nominating Committee" shall formulate a procedure for consultation or balloting and nominate candidates for the office of the Chief Executive. Members of the "Nominating Committee" shall not be candidates for the office of the Chief Executive.

5. Members of the "Nominating Committee" shall be elected, recommended or selected through consultation by corporate bodies or noncorporate permanent organizations in various fields. Rules of the "Nominating Committee" shall be prescribed by the laws of the Hong Kong Special Administrative Region.

6. The Hong Kong Special Administrative Region shall stipulate by law the provisions for constituency registration and voting procedures for a one-person-one-vote general election of the Chief Executive. 


\section{Annex II Method for Constituting the Legislative Council of the Hong Kong Special Administrative Region}

\section{Alternative 1}

1. The legislature of the Hong Kong Special Administrative Region shall be composed of 80 persons. The proportions of representation shall be as follows:

$\begin{array}{ll}\text { Members elected by functional bodies } & 50 \% \\ \text { Members directly elected by districts } & 25 \% \\ \text { Members elected by the electoral college } & 25 \%\end{array}$

2. The composition of the electoral body and the nominating committee shall be the same as that prescribed in Alternative 1, "Method for Selecting the Chief Executive of the Hong Kong Special Administrative Region", and the chairman of the nominating committee shall be the Chief Executive.

3. In the above three types of election, each person can vote and stand for election only in one.

4. The term of office of the members of the legislature shall be four years, and half the members shall be elected very two years. The functional bodies shall elect half of their members to the legislature every two years. The direct election in the districts and the election by the electoral college shall be held alternately every two years, (District direct elections and elections of the Chief Executive shall take place in the same year.)

5. District direct elections: Hong Kong shall be divided into 10 constituencies, with two seats for each constituency, and the two candidates with the first and second highest number of votes shall be elected.

6. Detailed election rules shall be prescribed by the laws of the Hong Kong Special Administrative Region.

\section{Alternative 2}

1. The legislature of the Hong Kong Special Administrative Region shall be constituted as follows: No less than 50 per cent of the members shall be directly elected in a general election; no more than 25 per cent shall be elected by the functional bodies, and no more than 25 per cent shall be elected by district organi- 
zations (i.e. District Boards, Urban Council and Regional Council or other similar organizations.)

2. The direct election of the legislature must be genuine and held at regular intervals. The right to vote must be universal and equal. Election should be by secret ballot so as to ensure free expression of the will of the voters.

3. Detailed rules for the election of the legislature shall be prescribed by the laws of the Hong Kong Special Administrative Region.

\section{Alternative 3}

1. The legislature of the Hong Kong Special Administrative Region shall have 60 members.

2. Thirty per cent of the members (i.e. 18 persons) shall be elected by the advisory group from among non-advisers. At least onethird of these members (i.e. 6 persons) shall be principal officials, and the rest (around two-thirds) shall be members of the Executive Council and other public figures. (Members of the legislature elected by the advisory group must include members of the Executive Council and principal officials so as to strengthen the links between the executive and the legislature.)

3. Forty per cent of the members (i.e. 24 persons) shall be elected by functional bodies.

4. Thirty per cent of the members shall be elected directly by the districts. The members of the legislature directly elected and those elected by the advisory group shall be roughly the same in numbers and shall be elected roughly at the same time, so that balance can be maintained. (Unless the method of the election by the advisory group is accepted, direct election cannot be held.)

5. The two election methods stated above in paragraphs 3 and 4 shall be prescribed in detail by law.

\section{Alternative 4}

1. The composition of the legislature of the Hong Kong Special Administrative Region shall be as follows:

From business circles

From the professions

From grass-roots organizations 
2. The composition is thus divided into four major categories. The first three major categories are further divided into sub-categories according to trades or professions. The delimitation of each sub-category and the number of members it elects to the legislature shall be prescribed by the laws of the Hong Kong Special Administrative Region.

All members of the legislature who belong to the three major categories shall be elected from corporate bodies in accordance with law.

According to the assigned number of seats, each corporate body shall decide on its own which of the following methods to adopt for electing its members to the legislature:

(1) Each member is directly elected on a one-person-one-vote basis;

(2) Members from its subsidiaries are elected through indirect election on a one-unit-one-vote basis; and

(3) The general membership conference authorizes a council to elect members through indirect election.

3. The division of the district constituencies, the voter registration, the voting procedures, and the nomination of candidate in district general elections shall be prescribed by the laws of the Hong Kong Special Administrative Region.

(Notes)

1. The members who put forward Alternatives 1 and 3 maintained that their proposed methods for electing members of the legislature are "package" deals, that is to say, direct district election is conditional upon the accpetance [sic] of the other two types of election.

2. Some members proposed that all the members of the legislature of the Hong Kong Special Administrative Region be elected by the functional bodies and that the method of election by the functional bodies be the same as that in Alternative 3 in Annex I.

3. A member proposed that all the members of the legislature of the Hong Kong Special Administrative Region be elected by districts through direct election on a one-person-one-vote basis. The election of the legislature must be genuine and held at regular intervals. The right to vote must be universal and equal. The election must be by secret ballot so as to ensure free expression of the will of the voters.

4. A member proposed that the method of general election on a one-person-one-vote basis should be considered together with the question of nationality, and studies must be made on the 
right to vote and to stand for election of Hong Kong permanent residents who have moved to a foreign country (but might not have acquired foreign nationality). 


\section{Annex III Method for the Formation of the First Government and the First Legislative Council of the Hong Kong Special Administrative Region}

1. Within the year of 1996, the National People's Congress shall establish a Preparatory Committee of the Hong Kong Special Administrative Region, which shall be responsible for the preparations of the establishment of the Region, and shall decide on the specific method for the formation of its first government. The preparatory committee shall be composed of mainland members and of Hong Kong members who shall constitute no less than 50 percent. Its chairman and members shall be appointed by the Standing Committee of the National People's Congress.

2. The Preparatory Committee for the Hong Kong Special Administrative Region shall be responsible for preparing the establishment of the "Election Committee for the First Government of the Hong Kong Special Administrative Region".

The "Election Committee" shall be composed entirely of permanent residents of Hong Kong and must be broadly representative. It shall include deputies of the Hong Kong region to the National People's Congress of the People's Republic of China, Hong Kong members of the National Committee of the Chinese People's Political Consultative Conference, experienced persons who have served in Hong Kong's administrative, legislative and advisory organizations before the establishment of the Hong Kong Special Administrative Region, as well as persons representative of all strata and sections of society.

The proportions of the composition of the "Election Committee" are tentatively proposed as follows:

Persons from business and financial circles $25 \%$

Professionals $25 \%$

Persons from labour, grass-roots and religious organizations

Political figures of former times $20 \%$

Deputies to the National People's Congress and members of the National Committee of the Chinese People's Political Consultative Conference 
3. The "Election Committee" shall formulate procedures and accordingly recommend the candidate for the first Chief Executive through local consultation or through local election after consultation, and report the recommended Chief Executive to the Central People's Government for appointment. The term of office of the first Chief Executive shall be the normal term.

4. The Chief Executive of the Hong Kong Special Administrative Region shall be responsible for preparing the election of the first government of the region according to this Law.

5. The first (or provisional) legislature of the Hong Kong Special Administrative Region shall be elected by the "Election Committee". All members of the former Hong Kong Legislative Council can be candidates for membership in the first (or provisional) legislature of the Region.

The term of office of members of the first (or provisional) legislature of the Hong Kong Special Administrative Region shall be two years.

6. The first Chief Executive of the Hong Kong Special Administrative Region shall be sworn in to office on 1 July 1997. On 1 July 1997, the first government and legislature of the Hong Kong Special Administrative Region shall be inaugurated simultaneously.

1. The members proposed that a map showing the administrative boundaries of the Hong Kong Special Administrative Region be published by the State Council when the Basic Law is promulgated by the National People's Congress.

2. The proposal on the establishment of the Committee for the Basic Law of the Hong Kong Special Administrative Region put forward by the Sub-group on the Relationship Between the Central Authorities and the Hong Kong Special Administrative Region reads as follows:

(1) Name: To be called tentatively the Committee for the Basic Law of the Hong Kong Special Administrative Region of the Standing Committee of the National People's Congress.

(2) Affiliation: To be a subordinate organ of the Standing Committee of the National People's Congress.

(3) Duties: To study and submit its views to the National People's Congress or its Standing Committee on the following questions:

(a) Questions on whether laws enacted by the legislature 
of the Hong Kong Special Administrative Region are in conformity with the Basic Law and legal procedures (Article 16 of the Draft Basic Law for Solicitation of Opinions);

(b) Questions relating to the applicability of nation-wide laws in the Hong Kong Special Administrative Region (Article 17);

(c) Questions relating to the interpretation of the Basic Law (Article 169); and

(d) Questions relating to the amendment of the Basic Law (Article 170).

(4) Composition: To be composed of mainland members and Hong Kong members, including persons from the legal profession, appointed by the Standing Committee of the National People's Congress. The number of its members and the proportions of its composition remain to be determined.

3. The names of the different departments of the executive authorities of the Hong Kong Special Administrative Region shall tentatively be called:

(1) The three main departments: the Department of Administration, the Department of Finance and the Department of Justice shall be called si, or "departments" in English, and those heading them shall be called Administrative Secretary, Financial Secretary and Secretary of Justice respectively.

(2) Those departments with policy-making powers shall be called $j u$, or "bureaus" in English, such as the Bureau of Finance, the Bureau of Industry and Commerce, the Bureau of Transport, the Bureau of Education and Manpower and the Civil Service Bureau.

(3) Those departments which carry out administrative duties and do not make policies shall be called chu, or "divisions" in English, such as the Police Division, the External Affairs Division and the Immigration Service Division.

(4) Those departments whose work is relatively independent shall be called shu, or "commissions" in English, such as the Commission against Corruption and the Commission of Audit.

4. The members held that in general, principal officials should be selected from among public servants. However, they can also be selected from among prominent members of society other than public servants. Principal officials of the latter type would be remunerated as public servants working on contract. They 
would leave the service on expiry of their terms of office. Transfers of principal officials and increase of officials of the Secretary level must be reported to the Central People's Government for approval.

5. The members agree that the English translation of （立法會議 ） shall continue to be "Legislative Council".

6. Whether or not members of the legislature should be required to resign after being appointed principal officials in the executive authorities remains to be studied.

7. "Judges" of the courts of the Hong Kong Special Administrative Region refers to judges of the district courts or above. Other members of the judiciary include magistrates of magistrates' courts and presiding officers at special tribunals. Other persons working in the judiciary are considered public servants.

8. The members held that if the present three-tier structure was retained, district boards should still be district consultative bodies. 
A Collection of Opinions and Suggestions of Some Members in Regard to the Articles Drafted by Their Respective Subject Subgroups

\section{CHAPTER I}

\section{Article 2}

1. A member proposed the Article be revised as follows:

"The National People's Congress authorizes the Hong Kong Special Administrative Region to exercise a high degree of autonomy in accordance with the provisions of this Law. The power of supervision over the implementation of this Law shall be vested in the Standing Committee of the National People's Congress. Any executive, legislative or judicial act which exceeds the powers authorized by this Law may be declared null and void by the Standing Committee of the National People's Congress."

2. Another member proposed the following amendment: "Except for foreign affairs and defence which are the responsibility of the Central People's Government, the Hong Kong Special Administrative Region shall enjoy a high degree of autonomy."

\section{Article 10}

A member proposed that the last phrase of Paragraph 1 be revised to read: "shall be ultimately based on the provisions of this Law." And the second paragraph should become a separate article.

\section{CHAPTER II}

Article 13

A member proposed that there should be separate laws to deal with offences committed by members of the garrison.

\section{Article 16 Paragraph 3}

1. A member proposed that the Paragraph be revised to read: "If the Standing Committee of the National People's Congress, after consulting the Committee for the Basic Law of the Hong Kong Special Administrative Region, considers any law of the Region not to be in conformity with this Law or legal procedures, it may refer the law in question to the Court of Final Appeal for its consideration. If the court considers the law or a 
part thereof not to be in conformity with this Law or legal procedures, it may declare that the law or the part thereof null and void, but the declaration shall not have retroactive effect."

2. A member proposed that the last clause of Paragraph 3 of Article 16 be amended to read: "This cessation shall not have retroactive effect except in criminal and constitutional cases."

Article 17

A member proposed that the Article be amended to read: "The laws of the Hong Kong Special Administrative Region shall be this Law, the laws previously in force in Hong Kong as provided in Article 8 of the General Principles of this Law, and laws enacted by legislature of the Region.

"Laws enacted by the National People's Congress or its Standing Committee shall not apply in the Hong Kong Special Administrative Region except for those relating to defence and foreign affairs and other matters which, according to the provisions of this Law, are outside the limits of the high degree of autonomy of the Hong Kong Special Administrative Region.

"Whenever there is need to apply in the Hong Kong Special Administrative Region any of the above-mentioned laws concerning defence and foreign affairs, they shall be applied by way of legislation by the legislature of the Region on the directives of the Standing Committee of the National People's Congress.

"Except in cases of emergency, the Standing Committee of the National People's Congress shall consult its Committee for the Basic Law of the Hong Kong Special Administrative Region and the government of the Region before issuing the above-mentioned directives.

"If the legislature of the Hong Kong Special Administrative Region fails to act in compliance with the directives of the Standing Committee of the National People's Congress, the Standing Committee may promulgate and apply the above-mentioned law in the Hong Kong Special Administrative Region through the Chief Executive of the Region.

"Apart from the laws concerning defence and foreign affairs as mentioned above, a few nation-wide laws which give expression to national unity and territorial integrity (as listed in the appendix of this Law) shall be applicable in the Hong Kong Special Administrative Region."

Article 18

Some members put forward the following two alternatives: 


\section{Alternative 1}

The courts of the Hong Kong Special Administrative Region shall continue to have jurisdiction over cases originally under the jurisdiction of courts in Hong Kong, except for those listed in the following Clauses (1) to (4):

(1) Cases relating to the relationship between the Central Authorities and the Hong Kong Special Administrative Region;

(2) Cases relating to the validity of executive acts (including defence and foreign affairs) of the Central Authorities;

(3) Cases relating to the validity of executive acts of the government of the Hong Kong Special Administrative Region in implementing, in accordance with the provisions of this Law, the directives of the Central Authorities concerning defence and foreign affairs; and

(4) Cases relating to the validity of those executive acts of the government of the Hong Kong Special Administrative Region in dealing with external affairs on its own as authorized by the Central Government and in accordance with the provisions of this Law, which were deemed to be "acts of state" under the laws previously in force in Hong Kong, and cases relating to the contents of the executive acts which were deemed to be "facts of state" under the laws previously in force in Hong Kong.

The courts of the Hong Kong Special Administrative Region shall seek the advice of the Chief Executive when questions mentioned in Clauses (1) to (4) arise in any legal proceedings. A statement issued by the Chief Executive regarding the matter shall be binding on the courts.

Before issuing such a statement, the Chief Executive shall obtain a certificate from the Standing Committee of the National People's Congress or the State Council.

(Explanatory note: The types of cases listed in the Clauses (1) to (4) above are not suitable for a court under a local government to try, although the court enjoys power of final adjudication.)

\section{Alternative 2}

The courts of the Hong Kong Special Administrative Region shall have jurisdiction over all cases in the Region, except that the restrictions of their jurisdiction imposed by Hong Kong's previous legal system and principles shall be maintained.

The courts of Hong Kong Special Administrative Region shall seek the advice of the Chief Executive in accordance with the principles and legal precedents of the common law when questions concerning foreign affairs and defence arise in any legal proceedings. A statement issued by 
the Chief Executive regarding such questions shall be binding on the courts.

Before issuing such a statement, the Chief Executive shall obtain a certificate from the Standing Committee of the National People's Congress or the State Council.

Regulations regarding the handling by courts of the Hong Kong Special Administrative Region of cases relating to organizations, organs of state power or their personnel of the People's Republic of China (including those mentioned in Articles 13 and 21 of Chapter 2), and regulations concerning compensations by organizations, organs of state power and the personnel concerned, shall be stipulated by the law of the Region.

\section{Article 20}

A member proposed that the Article be revised to read: "Chinese nationals holding identity cards as permanent residents of the Hong Kong Special Administrative Region are entitled to participate in the state affairs as prescribed by law. In accordance with the assigned number of seats and the election procedures specified by the Standing Committee of the National People's Congress, Chinese nationals who are permanent residents of the Region shall elect Chinese nationals of the same status to be deputies of the Region to the National People's Congress.

"The deputies of the Hong Kong Special Administrative Region to the National People's Congress shall not interfere in the affairs which the Region administers on its own in accordance with this Law."

\section{CHAPTER III}

\section{Article 24}

A member proposed that the Article be revised to read: "Hong Kong residents shall be equal before the law. They shall not be subject to discrimination on grounds of nationality, race, ethnic origin, language, sex, occupation, religious belief, political views, educational level, or property status."

\section{Article 25}

Some members proposed that this Article be revised to read: "Permanent residents of the Hong Kong Special Administrative Region shall have the right to vote and the right to stand for election as prescribed by law." 


\section{Article 26}

Some members proposed the adoption of the wording: "Hong Kong residents shall, in accordance with law, have". [sic]

\section{Article 29}

A member proposed the deletion of "except in cases where, to meet the needs of public security or of investigation into criminal offences, ..." from the Article. But after deliberation by the Subgroup, the clause is retained.

\section{Article 31}

1. Some members proposed that a third paragraph be added to this Article: "No person shall be subject to discrimination or impairment of his/her civil rights on grounds of religious belief."

2. Some members proposed that the Article be rewritten as follows:

"Residents of the Hong Kong Special Administrative Region shall have the right to freedom of thought, conscience and religion. These rights shall include the freedom to have or to adopt a religion or belief of one's choice, and freedom, either individually or in community with others and in public or private, to manifest one's religion or belief in worship, observance, practice and teaching."

Article 34

1. Some members proposed that the word "legitimate" as in "legitimate rights and interests" be deleted.

2. As to whether Hong Kong residents shall have the right to challenge in the Hong Kong courts the actions of the offices of the Central Authorities and their personnel in Hong Kong, the Subgroup on the Fundamental Rights and Duties of the Residents proposed that provisions be made for it by the relevant subgroup under the subject of jurisdiction.

\section{Article 41}

A member proposed that this Article be revised to read: "Persons in Hong Kong other than Hong Kong residents shall, in accordance with law, enjoy the rights and freedoms (except the right to vote and to stand for election) of Hong Kong residents prescribed in this Chapter." After deliberation the Subgroup on the Fundamental Rights and Duties of the Residents found that apart from the right to vote and to stand for election, there are a few other rights, such as the rights to free entry into 
Hong Kong, which "other persons" cannot enjoy. The Article thus remains unchanged.

\section{Chapter IV}

Article 43

A member proposed that this Article be revised to read: "The Chief Executive of the Hong Kong Special Administrative Region is the head of the Region and the head of the executive organs of the Region, representing the Region and leading its executive organs, and shall be accountable to the Central People's Government, the Hong Kong Special Administrative Region, and the legislature of the Region in accordance with the provisions of this Law."

\section{Article 44}

A member proposed that this Article be revised to read: "The Chief Executive of the Hong Kong Special Administrative Region shall be a Chinese national of no less than 40 years of age who is a permanent residents [sic] of the Region, who has ordinarily resided in Hong Kong for 20 years and who, before assuming office, has resided in Hong Kong for a continuous period of 10 years.

\section{Article 46}

Some members held that the term of office of the Chief Executive should be considered in conjunction with the term of office of members of the legislature. The term of office for both should be four years, and the Chief Executive may serve two consecutive terms.

\section{Article 47}

Some members pointed out that the question of restrictions on the occupation of retired Chief Executives and principal officials has yet to be studied. A member proposed adding the following content to this Article: "The Chief Executive, on assuming office, must resign from all other positions with pay or remuneration."

\section{Article 48 Clause (1)}

Some members held that if government was understood in its broad sense this Clause should read: "to lead the executive authorities of the Hong Kong Special Administrative Region."

Article 48 Clause (11)

A member proposed that this Clause be revised to read: "To ap- 
prove (or to disapprove) public officers appearing before committees under the legislature to testify or to give evidence with regard to matters relating to the navy, army or air force, the security of Hong Kong, or the responsibility of the Central People's Government over the administration of the Hong Kong Special Administrative Region.

\section{Article 48}

A member proposed that the following paragraph be added: "To exercise other powers, which are necessary and reasonable for carrying out his duties." Another member proposed that it be revised to read: "To exercise other powers prescribed in this Law."

\section{Article 52}

A member held that a Clause (4) should be added to this Article: "When vote of non-confidence is passed against the Chief Executive by a two-thirds majority of the members of the legislature." Another member held that if such a provision were to be included in the Article, it should specify that the Chief Executive could dissolve the legislature after its vote of non-confidence against him, but the Chief Executive would have to resign if the newly-elected legislature again cast a vote of nonconfidence.

\section{Article 54}

A member did not agree to the establishment of an Executive Council.

Article 55

1. Some members held that to serve on the Executive Council members of the legislature had to be elected by the legislature and eminent members of the public required the endorsement of over half of the members of the legislature. Another member held that without an election by the legislature, members could not serve on the Executive Council.

2. As to the size of the Executive Council and whether there is a need for a proportion of its composition, a member held that the Council should be composed entirely of principal officials; another member held that at least half of the membership of the Council should be members of the legislature. Members agreed that no stipulations would be made for the time being pending further study. 
Article 58

A member proposed that this Article be rewritten as follows: "The Chief Executive may appoint or remove the Commissioner of Audit with the approval of the legislature of the Hong Kong Special Administrative Region. In discharging their functions in accordance with law, the Commission of Audit and the Commission of Audit under him shall not be subject to any restriction by way of directive or control of any person or organ."

Article 60

A member proposed that this Article be rewritten as follows: "Members of the executive authorities shall include: (1) The Chief Executive; (2) Principal officials nominated by the Chief Executive and appointed by the Central Government (officials corresponding to the Secretary level); (3) Members of the Executive Council, including the Chief Executive and principal officials appointed by him."

Article 62

A member proposed adding a Clause (6): "Other powers which are necessary and reasonable for carrying out its duties in accordance with the provisions of this Law."

Article 64

Some members did not agree to the use of the colon after "accountable ... in the following respects" on the ground that the scope of matters for which the executive authorities are accountable would be wider than that covered by this Article.

They proposed that this Article be revised to read: "The executive authorities of the Hong Kong Special Administrative Region must abide by the law and shall be accountable to the legislature of the Region. They shall (1) implement laws passed by the legislature and already in force; (2) present regular reports on their work to the legislature; (3) be subject to supervision by the legislature; (4) answer questions raised by members of the legislature, and be subject to or assist in investigations by the legislature on special issues; and (5) obtain approval from the legislature for taxation and public expenditure, and be subject to supervision by the legislature in respect to public expenditure."

\section{Article 66}

Some members proposed that a second paragraph be added to this Article: "The legislative power of the Hong Kong Special Administrative Region is vested in the legislature of the Region." However, a mem- 
ber held that the wording should read: "The legislative power of the Hong Kong Special Administrative Region is vested in the Hong Kong Special Administrative Region".

\section{Article 70}

Most members were in favour of Alternative 1; some members were in favour of Alternative 2.

\section{Article 71 Clause (2)}

Some members believed that the agenda should be decided on by the Chief Executive.

\section{Article 72 Clause (5)}

A member proposed that this Clause be revised to read: "To review and question the work of the executive authorities".

\section{Article 72 Clause (9)}

1. A member proposed that the legislature should be able to pass a vote of non-confidence with a two-thirds majority against the Chief Executive or any principal official on a motion jointly proposed by one-fourth of the members of the legislature, and it should report the non-confidence motion to the Central People's Government for the dismissal of the Chief Executive or the principal official concerned. But most members did not agree.

2. Some members believed that the proportions as prescribed by Clause (9) are too low, and the wording also contains some faults. They proposed rewriting the Clause to read: "If over 50 per cent of all the members of the legislature suspect the Chief Executive of being guilty of serious breach of law or dereliction of duty, a joint motion can be proposed to establish an independent investigating committee in accordance with law. This committee, headed by the Chief Justice of the Court of Final Appeal, shall be responsible for carrying out investigations and reporting its findings to the legislature. If the committee considers the evidence sufficient, the legislature may pass motion of impeachment with a three-quarters majority and report it to the Central People's Government.

\section{Article 72}

1. A member proposed the inclusion of the following clause: "The legislature and its subordinate committees shall have the power 
to summon the person concerned to appear before them to testify and give evidence."

2. A member proposed that a provision for the establishment of standing committees and ad hoc committees should be added to this Article. But another member held that such a provision should be covered by the standing orders of the legislature.

3. A member proposed adding a Clause (10) to this Article: "Other powers which are necessary and reasonable for carrying out its functions in accordance with the provisions of this Law".

Article 73

A member held that bills relating to public expenditure of public policies should be jointly proposed by no less than one-tenth of the members of the legislature, but that the prior written consent of the Chief Executive should not be required.

\section{Article 74}

Some members pointed out that the quorum for meetings of the legislature could be less than half but no less than one-third of its total members and that it would not be easy to call a meeting if the quorum was set too high.

\section{Article 84}

A member proposed that after the phrase "free from any interference" in this Article, the following words should be added: "but subject to the supervision of the Standing Committee of the National People's Congress in regard to the question of whether the jurisdiction stipulated by this Law has been exceeded".

\section{Article 86}

A member proposed that the principles and rights mentioned in this Article should be specified in an appendix.

\section{Article 87}

1. A member pointed out that it was not desirable to have too many members in the independent commission and that its recommendations should be made with unanimity.

2. Some members pointed out that this Law should specifically provide for the independent finance of or special appropriation of funds for the judicial organs. 
Article 100

1. A member suggested that it might not be necessary to exclude foreign nationals from consideration for the post of Deputy Director for Civil Service.

2. A member pointed out that whether the posts of the Commission of Immigration and Inspector General of Customs and Excise should be subject to restriction could be further considered, since these two posts were not ranked at Secretary level.

Article 102

A member proposed that the following be added at the end of this Article: "The government of the Hong Kong Special Administrative Region may develop and improve the above system in accordance with law and in the light of actual conditions, in order to raise the efficiency of work and the quality of public servants".

Article 103

A member proposed that this Article should be placed in the General Principles. Most members maintained that it should remain as Article 103 for the time being and that decision should be made after overall consideration by the general working subgroup.

\section{Chapter V}

Article 105

Some members held that Paragraph 2 could be omitted from the Basic Law.

Article 107

A member held that this Article could be omitted from the Basic Law.

Article 111

1. A member proposed that the words "foreign currencies" should be inserted into this Article.

2. A member proposed that the word "commodity" should be added before the word "futures".

Article 135

The Subgroup on Economy suggested that the question of what "foreign military aircraft" includes be restudied and made specific. 


\section{CHAPTER IX}

Article 169

A member proposed that the Article be revised as follows: "The power of interpretation of this Law is vested in the Standing Committee of the National People's Congress. The courts of the Hong Kong Special Administrative Region may interpret all the provisions of this Law.

"Regarding the provisions which are within the limits of the autonomy of the Hong Kong Special Administrative Region, the Standing Committee of the National People's Congress will grant full power to the courts of the Region to interpret them when adjudicating cases.

"When the Standing Committee of the National People's Congress makes an interpretation of a provision of this Law which is outside the limits of the autonomy of the Hong Kong Special Administrative Region, the courts of the Region, in applying such a provision, shall follow the interpretation of the Standing Committee. However, cases under adjudication and judgments previously rendered shall not be affected.

"The Standing Committee of the National People's Congress shall consult its Committee for the Basic Law of the Hong Kong Special Administrative Region before giving an interpretation of this Law.

"Provisions of Chapters 3, 4, 5, 6, and 10 are all within the limits of the autonomy of the Hong Kong Special Administrative Region. Whether the provisions of other Chapters are within the limits of the autonomy of the Region may be decided by the courts of the Region or by the Standing Committee of the National People's Congress. The Standing Committee will consult the Committee for the Basic Law of the Hong Kong Special Administrative Region before making a decision. The decision of the Standing Committee of the National People's Congress shall be final.

\section{Article 170}

1. A member proposed that the Article be revised as follows:

"The power of amendment of this Law is vested in the National People's Congress.

"The right to propose amendments to this Law rests with the Standing Committee of the National People's Congress, the State Council and the Hong Kong Special Administrative Region. Amendment proposals from the Region shall be submitted to the National People's Congress through the State Council after obtaining the consent of two-thirds of all the members of the legislature of the Hong Kong Special Administrative Region and the Chief Executive of the Region.

"Before a proposal for an amendment to this Law is put on the agenda of the National People's Congress, the Committee for the Basic 
Law of the Hong Kong Special Administrative Region shall first study it and submit its views. No amendment to this Law shall contravene the established basic policies of the People's Republic of China regarding Hong Kong as stated in the Preamble."

2. A member proposed that Paragraph 2 be revised as follows: "The right to propose amendments to this Law rests with the Standing Committee of the National People's Congress, the State Council and the Hong Kong Special Administrative Region. Amendment proposals from the Region shall be submitted to the National People's Congress by the delegation of the Region to the National People's Congress after obtaining the consent of two-thirds of the deputies of the Region to the National People's Congress, and the Chief Executive of the Region."

\section{Chapter X}

\section{Article 171}

The Subgroup on Political Structure put forward the following alternatives:

1. A member proposed that Annex III be as follows:

(1) Before 1997, the Central Authorities shall form a preparatory committee composed of both Hong Kong and mainland members. An advisory group consisting of no less than 50 persons from various walks of life in Hong Kong, appointed by the preparatory committee shall, through local consultation, select the Chief Executive for appointment by the Central Authorities.

(2) The Chief Executive shall form the Executive Council and nominate the principal officials for appointment by the Central Authorities.

(3) The advisory group shall elect legislative members nominated by the Chief Executive in conjunction with the Executive Council to form a provisional Legislative Council.

(4) The term of office of all the members of the first government shall not exceed three years. A regular government must be formed within three years in accordance with this Law.

2. A member proposed that Annex III be as follows:

The candidate for the first Chief Executive designate of the Hong Kong Special Administrative Region shall be selected through local consultation on 1 December 1996 in accordance with the method stated in Annex I. The selected candidate shall, upon the endorsement of the Central People's Government, become the first Chief Executive designate.

Before 1 April 1997, the first Chief Executive designate shall nominate candidates to be the perspective members of the first Executive Council.

The first Chief Executive designate shall, in conjunction with the 
perspective members of the first Executive Council, organize the "Preparatory Committee for the Formation of the First Government". At zero hour on 1 July 1997, the first Chief Executive, after being officially appointed by the Central People's Government, shall with the assistance of members of the first Executive Council, proclaim the formation of the first government of the Hong Kong Special Administrative Region and shall, as authorized by the Central Authorities, take over the administration of the Region from the Standing Committee of the National People's Congress. Before the formation of the first legislature, a provisional legislature shall exercise provisional legislative power and may enact provisional ordinances if necessary.

(Explanatory note) The provisional legislature shall be elected by the electoral college locally in accordance with the method stated in the Annex. Members of the previous legislature who are relieved of their office on 30 June 1997 shall not be excluded from candidacy.

After the establishment of the first government of the Hong Kong Special Administrative Region, elections for the first District Boards and the first Urban Council shall be held within 6 months in accordance with the method stated in the Annex; and the first legislature shall be elected and formed within 12 months in accordance with the method stated in Annex II.

Appendix I: Procedures for the Selection of the First Chief Executive through Local Consultation by the Various Sectors in Hong Kong

After the promulgation of the Basic Law, the National People's Congress shall appoint no less than 50 members to form a "Preparatory Committee for the Implementation of the Basic Law". The duties of the committee will be diverse, including the drafting (by itself or by a subordinate special group), after consulting the various sectors, of the "consultation procedures" for review and approval by the National People's Congress.

On 1 July 1995, members of the "Preparatory Committee for the Implementation of the Basic Law" will elect from among themselves no less than 10 persons to form a "consultation committee" which shall organize open consultation in accordance with the "consultation procedures". Members of the "consultation committee" shall not be candidates for Chief Executive, nor shall they nominate or support any candidate for the Chief Executive. The "consultation committee", responsible for promoting and supervising the consultations, shall be objective and impartial.

A candidate for the first Chief Executive designate shall be selected on 1 December 1996 for endorsement by the Central Authorities and be officially appointed as the Chief Executive on 1 July 1997. 
Appendix II: Method of Election of the First Legislature

Electoral college-Half of the members of the legislature shall be elected by a broadly representative grand electoral college. No less than two-thirds of these shall be Chinese nationals.

Indirect election-One-fourth of the members of the legislature shall be elected from among members of the District Boards and the Urban Council who are Chinese nationals.

Direct election by function constituencies-One-fourth of the members of the legislature shall be directly elected by functional constituencies. (The functional constituencies shall be registered as legal persons in accordance with local laws and shall be of Chinese nationality. Regardless of their own nationalities, members of the legislature who are directly elected by functional constituencies may, by virtue of the Chinese nationality of the functional constituencies to which they belong, execise [sic] the civil rights of Chinese nationals during their term of office.)

3. Some members proposed that Annex III be as follows:

(1) The Standing Committee of the National People's Congress of the People's Republic of China shall appoint a "Preparatory Committee for the First Government of the Hong Kong Special Administrative Region". All the members of the committee shall be Chinese nationals, comprising mainland residents and Hong Kong permanent residents in equal number. The chairman of the committee shall be a member of the Standing Committee of the National People's Congress.

(2) The "Preparatory Committee for the First Government of the Hong Kong Special Administrative Region" shall entrust its Hong Kong members with the responsibility of forming an electoral college in Hong Kong which shall comprise representatives of the legislature and of district organizations prior to the establishment of the Hong Kong Special Administrative Region, representatives of corporate bodies and permanent non-corporate organizations, and representatives of various sectors of the community. The electoral college, which must be broadly representative, shall be called the "Electoral College for the First Government of the Hong Kong Special Administrative Region".

(3) The Electoral College for the First Government of the Hong Kong Special Administrative Region shall be responsible for drawing up the procedures for the selection of the first Chief Executive through consultation, or by election following nomination through consultation.

(The qualifications, powers, and functions of the Chief Executive shall provided for in Chapter IV of this Law.) 
(4) The Electoral College for the First Government of the Hong Kong Special Administrative Region shall be responsible for drawing up the procedures for the election of the first legislature. Members of the legislature before the establishment of the Hong Kong Special Administrative Region who meet the requirements of Chapter IV of this Law may be elected as members of the first legislature.

(The qualifications, powers, and functions of the members of the legislature shall be provided for in Chapter IV of this Law.)

(5) Government officials, public servants and members of the judiciary before the establishment of the Hong Kong Special Administrative Region who meet the requirements of this Law shall remain in employment in the first government.

(The composition, powers, and functions of the executive authorities shall be provided for in Chapter IV of this Law.)

4. A member proposed that Article 171 be as follows:

The first government of the Hong Kong Special Administrative Region shall be established according to the provisions of the Annex, "Method for the Formation of the First Government of the Hong Kong Special Administrative Region". The first Chief Executive and the members of the first legislature selected according to the provisions of this Annex shall be deemed to have been selected according to the provisions of Chapter IV of this Law. But the term of office of the first Chief Executive shall expire six months after the expiry of term of office of the members of the first legislature.

Appendix: Method for the Formation of the First Government of the Hong Kong Special Administrative Region.

(1) Within the year of 1996, the Standing Committee of the National People's Congress shall establish a "Preparatory Committee for the First Government of Hong Kong Special Administrative Region". Members of the preparatory committee shall all be Chinese nationals among the permanent residents of Hong Kong, and the chairman shall be elected from among the members.

(2) In the middle or at the end of 1996, the preparatory committee shall hold a general and direct election in Hong Kong in accordance with this Law to elect the Chief Executive designate. Only 1 July 1997, the Chief Executive designate shall be appointed by the Central People's Government and be officially sworn in to office.

(3) Before 1 July 1997, the Chief Executive designate shall nominate the principle officials of the Hong Kong Special Administrative Region for appointment by the Central People's 
Government. All the principal officials shall be sworn in to office on 1 July 1997.

(4) Persons who are members of the Hong Kong Legislative Council in June 1997 shall automatically become members of the first legislature of the Hong Kong Special Administrative Region on 1 July 1997 and serve to the end of their term. Except for the ceremony of pledging their loyalty to the Hong Kong Special Administrative Region, there shall be no particular arrangement.

5. Some members proposed that Article 171 be as follows:

"The first government of the Hong Kong Special Administrative Region shall be established through arrangements based on the principle of the sovereignty of the People's Republic of China and smooth transition for Hong Kong." The contents of the Annex to this Article shall not be stipulated for the time being. Decision shall be made after extensive consultation and detailed study.

[Note] The opinions and suggestions expressed by members at the seventh plenary session of the Drafting Committee concerning the articles in the Draft Basic Law for Solicitation of Opinions will be collated and published by the Secretariat after the session. 